\title{
UPAYA MENINGKATKAN MINAT BELAJAR MATEMATIKA DENGAN MODEL PEMBELAJARAN KOOPERATIF TIPE TEAM ASSISTED INDIVIDUALIZATION (TAI)
}

Sarinem, Ika Septi Hidayati, SD Negeri Tangkisan, Universitas Cokroaminoto Yogyakarta ikasepti58@gmail.com

\begin{abstract}
The purpose of this study was 1) to find out the application of the Team Assisted Individualization (TAI) Cooperative learning model in order to increase the learning interest of the fifth grade students of Tangkisan State Elementary School.. The results of this study indicate that: (1) In general, the application of the appropriate TAI learning model is effective in improving mathematics learning achievement, (2) Increased mathematics learning achievement of fifth grade elementary school students at Tangkisan at 61.07 in the first cycle of 75, 31 in the second cycle of 84.69.
\end{abstract}

Keywords: Team Assisted Individualization, learning interest

\begin{abstract}
Abstrak
Tujuan Penelitian ini adalah mengetahui penerapan model pembelajaran Kooperatif Tipe Team Assisted Individualization (TAI) yang tepat agar dapat meningkatkan minat belajar siswa kelas V SD Negeri Tangkisan. Hasil penelitian ini menunjukan bahwa: (1) Secara umum penerapan model pembelajaran TAI yang tepat, efektif dalam meningkatkan minat belajar matematika, (2) Peningkatan prestasi belajar matematika siswa kelas V SD Tangkisan pada pra siklus sebesar 61,07 pada siklus I sebesar 75,31 pada siklus II sebesar 84,69 .
\end{abstract}

Kata Kunci: Team Assisted Individualization, Minat belajar

\section{A. Pendahuluan}

1. Latar Belakang Masalah

Pendidikan merupakan usaha yang dilakukan untuk mengubah tingkah laku individu dalam kehidupan pribadinya atau kehidupan masyarakatnyaa, termasuk juga kehidupan dalam alam sekitarnya. Pembelajaran sendiri memiliki beberapa komponen yang terikat satu sama lain dan berhubungan secara fungsional. Komponen-komponen sistem pembelajaran antara lain: tujuan dan alat evaluasi. Semua komponen pembelajaran tersebut harus diorganisir secara baik agar menghasilkan proses pembelajaran yang menarik dan dapat meningkatkan minat peserta didik untuk belajar. Proses pembelajaran itu sendiri merupakan proses interaksi antara guru dan peserta didik dalam rangka mencapai pembelajaran.

Matematika merupakan salah satu mata pelajaran yang telah diajarkan kepada siswa sejak sekolah dasar, bahkan sebelum masuk ke sekolah formal seorang anak telah dikenalkan dengan matematika berupa hitung-hitungan yang sederhana sampai 
yang dianggap sulit dalam kehidupan sehari-harinya. Paradigma yang berkembang sampai saat ini baik di masyarakat maupun di lingkup para siswa terhadap mata pelajaran matematika adalah matematika merupakan mata pelajaran yang sukar, membosankan dan bisa dikatakan menakutkan. Hal tersebut dapat terlihat dari rendahnya prestasi hasil belajar matematika yang diperoleh rata-rata siswa di semua tingkat pendidikan dari tingkat sekolah dasar sampai tingkat sekolah menengah atas (Sukaryanto, 2012:1).

Matematika diajarkan bukan hanya untuk mengetahui dan memahami apa yang terkandung di dalam matematika itu sendiri, tetapi pada dasarnya matematika diajarkan untuk membantu melatih pola pikir siswa agar dapat memecahkan masalah secara kritis, logis, dan tepat. Mempelajari matematika membutuhkan simbol-simbol agar ide-ide atau konsep dapat dikomunikasikan. Banyaknya simbol yang digunakan terkadang membuat siswa pusing dan merasa bahwa matematika itu merupakan pelajaran yang paling sulit. Terlebih lagi para guru matematika biasanya menggunakan metode yang monoton yaitu ceramah yang cenderung membosankan sehingga membuat siswa semakin kesulitan dalam mempelajari matematika.

Minat memegang peranan penting dalam proses belajar mengajar.. Dalam kenyataannya tidak semua siswa belajar karena didorong oleh faktor minatnya sendiri, ada yang mengembangkan minatnya terhadap materi pelajaran dikarenakan pengaruh dari gurunya, temannya, atau orang tuanya. Oleh sebab itu, sudah menjadi kewajiban dan tanggung jawab guru untuk mengkondisikan kelas yang bisa membangkitkan minat siswa untuk belajar.

Permasalahan yang timbul pada pembelajaran matematika di SD Negeri Tangkisan Kokap Kulon Progo adalah rendahnya tingkat prestasinya. Dalam mengikuti proses pembelajaran matematika sebagian siswa kurang berkonsentrasi, tidak memperhatikan penjelasan guru, terutama siswa yang duduk di bangku belakang. Mereka sibuk dengan aktifitasnya sendiri, mengobrol dengan teman sebangku dan melamun. Kondisi tersebut kurang terpantau oleh guru, karena guru lebih dominan di depan kelas menerangkan materi pelajaran, kecuali siswa yang ribut di kelas langsung mendapat teguran dari guru.

Salah satunya guru dapat menerapkan model pembelajaran Kooperatif Tipe Team Assisted Individualization (TAI). Model pembelajaran ini dirancang khusus untuk meningkatkan kemampuan siswa dalam memahami konsep, menyelesaikan soal, dan memecahkan masalah-masalah matematika hingga pada akhirnya peserta didik mapu mengkonstruksikan jawaban mereka sendiri karena banyaknya pengalaman yang dimiliki peserta didik dalam menyelesaikan soal-soal latihan.

Melihat kenyataan dalam observasi di SD Negeri Tangkisan Kokap Kulon Progo maka peneliti tertarik untuk melakukan penelitian dengan judul "Upaya Meningkatkan Minat Belajar Matematika dengan Model Pembelajaran Kooperatif Tipe Team Assisted Individualization (TAI) pada siswa Kelas V SD Negeri Tangkisan Kokap Kulon Progo".

2. Teori yang digunakan

Minat Belajar

Minat belajar terdiri dari dua kata yakni minat dan belajar. Menurut Winkel (2004.p.212) minat adalah kecenderungan subjek yang menetap, untuk merasa tertarik pada bidang studi atau pokok bahasan tertentu dan merasa senang mempelajari materi itu. Menurut Arifin (2011.p.241) minat adalah dorongan atau aktivitas mental yang 
dapat merangsang perasaan senang terhadap sesuatu. Berminat tidaknya seseorang terhadap sesuatu dapat dilihat dari beberapa indikator yaitu perhatian, perasaan, motivasi, dan sikap. Sementara itu Slameto (2013.p.57) mengatakan minat adalah kecenderungan yang tetap untuk memperhatikan dan mengenang beberapa kegiatan, kegiatan yang diminati, diperhatikan terus-menerus yang disertai dengan rasa senang. Minat besar pengaruhnya terhadap belajar karena bila bahan pelajaran yang dipelajari tidak sesuai dengan minat siswa, siswa tidak akan belajar dengan sebaik-baiknya karena tidak ada daya tarik baginya. Bahan pelajaran yang menarik minat siswa, lebih mudah dipelajari dan disimpan karena minat menambah kegiatan belajar. Menurut Hamalik (2008.p.154-155) belajar adalah perubahan tingkah laku yang relatif mantap berkat latihan dan pengalaman. Belajar sesungguhnya adalah ciri khas manusia dan membedakannya dengan binatang. Belajar yang dilakukan oleh manusia merupakan bagian dari hidupnya, berlangsung seumur hidup, kapan saja, dan di mana saja baik di sekolah, di kelas, dan di jalanan dalam waktu yang tidak dapat ditentukan sebelumnya. Hasil belajar tampak sebagai terjadinya perubahan tingkah laku pada diri siswa yang dapat diamati dan diukur dalam bentuk perubahan pengetahuan sikap dan keterampilan. Perubahan tersebut dapat diartikan terjadinya peningkatan dan pengembangan yang lebih baik dibanding dengan sebelumnya misalnya dari tidak tahu menjadi tahu, sikap kurang sopan menjadi sopan dan sebagainya. Jadi, dapat ditarik kesimpulan bahwa belajar itu menimbulkan suatu perubahan tingkah laku yang relatif tetap dan perubahan itu dilakukan lewat kegiatan atau usaha yang disengaja. Berdasarkan pendapat di atas yang dimaksud dengan minat belajar adalah aspek psikologi seseorang yang menampakkan diri dalam beberapa gejala seperti gairah, keinginan, perasaan suka untuk melakukan proses perubahan tingkah laku melalui berbagai keinginan yang meliputi mencari pengetahuan dan pengalaman. Dalam minat belajar itu ada perhatian, perasaan suka, motivasi sebagai pendorong belajar, dan sikap dalam belajar.

\section{Metode Penelitian}

Penelitian ini merupakan Penelitian Tidakan Kelas (PTK). Penelitian Tindakan Kelas merupakan suatu penelitian yang akar permasalahannya muncul di kelas dan dirasakan langsung oleh guru yang bersangkutan sehingga sulit dibenarkan jika ada anggapan bahwa permasalahan dalam penelitian tindakan kelas diperoleh dari persepsi atau lamunan seorang peneliti (Arikunto, 2008.p.104). Penelitian ini dilakukan secara kolaboratif artinya peneliti bekerja sama dengan guru mata pelajaran yang bersangkutan sebagai satu tim, terlibat langsung dalam persiapan-persiapan yang diperlukan, refleksi tindakan, dan perencanaan dalam setiap siklus.

Subjek penelitian ini adalah siswa kelas V berjumlah 16 siswa di SD Negeri Tangkisan Kokap Kabupaten Kulon Progo. Objek penelitian ini adalah prestasi belajar matematika. Teknik pengumpulan data pada penelitian ini berupa observasites, dan dokumentasi. Instrumen penelitian ini adalah lembar tes.

Tes digunakan untuk mengetahui minat siswa terhadap materi yang dipelajari. Tes berupa soal pilihan ganda dan soal evaluasi. Dalam penelitian untuk menguji instrumen digunakan teknik uji coba terpakai, yaitu mengujicobakan instrumen sekaligus mengumpulkan data penelitian. Komponen-komponen yang menjadi indikator keberhasilan dalam penelitian ini yaitu $80 \%$ hasil belajar siswa kelas V SD 
Negeri Tangkisan Kokap Kulon Progo mengalami ketuntasan belajar matematika setelah penerapan model pembelajaran $T A I$ dengan batas tuntas $\mathrm{KKM}=76$.

\section{B. Hasil Penelitian dan Pembahasan}

1. Deskripsi Hasil

Untuk mengetahui sejauh mana peningkatan minat belajar pada setiap siklusnya. Dari hasil pengamatan dari pra siklus, siklus I, siklus II minat siswa dalam pembelajaran matematika meningkat. Siswa memperhatikan pelajaran dengan seksama, antuasias dalam mengikuti pembelajaran, meningkatkan rasa percaya diri.

Hasil rata-rata kelas yang dicapai pada siklus I adalah sebesar 75,31. Naik 14,24 poin dari rata-rata praskilus sebesar 65,18. Dari 16 siswa diperoleh 7 siswa yang mencapai KKM. Hasil rata-rata kelas yang dicapai pada siklus II adalah sebesar 84,69. Naik 9,38 poin dari rata-rata data siklus I sebesar 75,31. mengalami peningkatan yaitu $85,71 \%$ dengan kategori minat siswa sangat tinggi.

Peningkatan minatbelajar kategori tinggi kelas V SD Tangkisan dari pra siklus, Siklus I, dan Siklus II sebagai berikut.

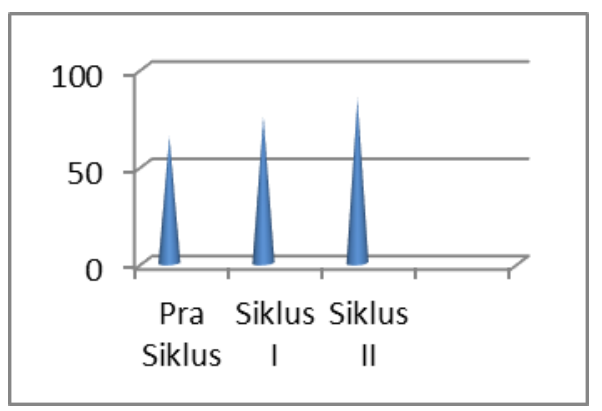

2. Pembahasan

Berdasarkan dari hasil analisis data-data yang dhimpun dari pelaksanaan penelitian dilapangan, peneliti akan mengemukakan data yang berhasil diperoleh sebagai berikut:

a. Penerapan model pembelajaran TAI mampu meningkatkan minat belajar matematika. Dari minat belajar matematika selama proses pembelajaran siklus I dan siklus II terdapat peningkatan minat belajar matematika. Peningkatan ratarata minat belajar dari pra siklus yang hanya 61,07 naik menjadi 75,31 di siklus I, naik menjadi 84,69 di siklus II.

b. Penerapan tindakan yang tepat dapat meningkatkan minat belajar, dilakukan memperhatikan sintaks yang telah disesuaikan dengan memperhatikan hal-hal sebagai berikut:

i. Guru memotivasi siswa.

ii. Guru memberikan banyak tanya jawab materi terutama siswa yang mengalami kesulitan. 


\section{Daftar Pustaka}

1. Arifin, Zainal. 2011. PenelitianPendidikan Metode dan Paradigma Baru. Bandung: PT Remaja Rosdakarya.

2. Arikunto, dkk. 2008. Penelitian Tindakan Kelas. Jakarta: Bumi Aksara.

3. Hamalik, Oemar. 2008. Perencanaan Pengajaran Berdasarkan Pendekatan Sistem. Jakarta: PT Bumi Aksara.

4. Slameto. 2013. Belajar dan Faktor-faktor yang Mempengaruhinya. Jakarta: Rineka Cipta

5. Sukaryanto, 2012. Upaya Meningkatkan Keaktifan dan Prestasi Belajar Matematika Dengan Metode Pembelajaran Kooperatif Tipe Group Investigation (GI) Siswa Kelas VII B SMP Taman Dewasa Ibu Pawiyatan Yogyakarta Tahun Ajaran 2011/2012. Skripsi Universitas Sarjanawiyata Tamansiswa.

6. Winkel, S J. 2004. Psikologi Pengajaran. Yogyakarta: Media Abadi 